\title{
Seagrass recovery in the Northern Wadden Sea?
}

\author{
Karsten Reise · Jörn Kohlus
}

Received: 14 May 2007 / Revised: 18 October 2007 / Accepted: 18 October 2007 / Published online: 15 November 2007

(C) Springer-Verlag and AWI 2007

\begin{abstract}
Aerial surveys on seagrass (Zostera spp.) indicate a three to fourfold increase in bed area from 1994 to 2006 with up to $100 \mathrm{~km}^{2}$ or $11 \%$ of intertidal flats in the Northfrisian Wadden Sea (coastal eastern North Sea), observed at seasonal maximum in August when flying during low tide exposure 300 to $500 \mathrm{~m}$ above ground. When viewed from the air, difficulties in distinguishing between seagrass and green algae and a lack of contrast on dark-coloured mudflats are sources of error in areal estimates. Particularly the positioning of beds remote from shores was imprecise. However, the consistency in method over time gives confidence to the inferred positive trend which is opposite to the global pattern. Both, the spatial pattern and a recent decrease in storminess suggest that sediment stability is the key factor for seagrass dynamics in this tidal area. On exposed sand flats, high sediment mobility may be limiting and along the sheltered mainland shore land claim activities with high accretion rates may cause a scarcity of seagrass. The potential area of seagrass beds may be twice as large as the realized maximum in 2006 but eventually the rising sea level will reverse the observed seagrass expansion.
\end{abstract}

Keywords Aerial survey $\cdot$ Green algae $\cdot$ Intertidal · Land claim $\cdot$ Sediment stability $\cdot$ Zostera

Communicated by J. van Beusekom.

K. Reise $(\bowtie)$

Alfred Wegener Institute for Polar and Marine Research, Wadden Sea Station Sylt, Hafenstrasse 43, 25992 List, Germany e-mail: Karsten.Reise@ awi.de

\section{J. Kohlus}

Landesamt für den Nationalpark Schleswig-Holsteinisches

Wattenmeer, Schlossgarten 1, 25832 Tonning, Germany

e-mail: Joern.Kohlus@ nationalparkamt.de

\section{Introduction}

Seagrasses are a functional group of flowering plants with limnic ancestors which colonized coastal oceans (Short et al. 2007). In the North Sea they occur with two species of the eelgrass genus Zostera (den Hartog 1970). Important ecosystem functions in the North Sea are that (1) beds of seagrass provide shallow water habitats for a diversity of organisms including a nursery for fish, (2) waterfowl feed on eelgrass but quantitatively the contribution to the detrital food web prevails, and (3) beds of seagrass with associated organisms constitute an effective filter for nutrients and trap particulate matter (Asmus and Asmus 2000; Nacken and Reise 2000; Polte et al. 2005). Furthermore, persistent seagrass beds are considered excellent indicators of ecosystem health because they reflect temporally integrated environmental conditions and are rather easy to assess (Borum et al. 2004).

In the northern Wadden Sea, which is a coastal part of the eastern North Sea with extensive intertidal mud and sand flats, meadows occur mostly in the upper to mid tidal zone. From June to September meadows give a conspicuous dark shade when viewed from the air. Beds often exhibit a topography of hummocks and runnels where $Z$. noltii is more tolerant to desiccation and gives rise to hummocks while Zostera marina prefers puddles and runnels (den Hartog 1971). In the intertidal zone of the Wadden Sea, Z. marina is mostly an annual and Z. noltii mostly a perennial plant.

Historically, Z. marina was growing in the shallow subtidal and lower to mid intertidal, while $Z$. noltii occurred in the mid to upper intertidal near the island of Sylt in the northern Wadden Sea (Nienburg 1927). A wasting disease in the 1930 wiped out the subtidal Z. marina (Wohlenberg 1935) and it never came back while intertidally both 
species survived (Reise et al. 1989). The same happened in the southern Wadden Sea (Harmsen 1936) but there also the intertidal beds of eelgrass declined since the second half of the last century (de Jonge et al. 1993, Kastler and Michaelis 1999). Experimental studies suggested that coastal nutrient over-supply may have been a major cause of the decline in the intertidal (e.g. Philippart 1995; van Katwijk et al. 1997, 1999).

As part of the Trilateral Monitoring and Assessment Program (TMAP) of the Wadden Sea, we started in 1994 with regular aerial surveys to assess seagrass occurrence in the northern Wadden Sea in an attempt to test whether the decline observed in the south will extend to the north. Instead, we found the largest seagrass area of the Wadden Sea gradually increasing over the years. Although an aerial survey alone cannot reveal the causes of observed patterns, we discuss whether the recent trend may constitute a recovery and use our observational data to make novel suggestions for research.

\section{Methods}

Surveying followed a simple procedure. With a Cessna type of airplane we were flying in an meander-like course at heights between 300 to $500 \mathrm{~m}$ across an area of $80 \times 30 \mathrm{~km}$ with $930 \mathrm{~km}^{2}$ of intertidal sediment flats as potential seagrass area. This area is located between Eiderstedt peninsula, the northern tip of the island of Sylt and the DanishGerman border, and is called the Northfrisian Wadden Sea. Flying time was $2-3 \mathrm{~h}$ around low tide period which is shifting from southwest to northeast with a maximum lag of $2 \mathrm{~h}$. Flights were performed each year in June, July and August/September to keep track of seasonal development. Together with an experienced pilot, four observers were on board and three of them were taking notes on maps 1:100,000 making decisions on position and identity of dark shading: seagrass, green algal mats or both mixed. In case of uncertainty, questionable darkish to greenish areas were flown over twice or more and looked at from various angles and heights to reach consensus. We assume that seagrass beds with $<20 \%$ coverage are not included in this aerial survey. This assumption is based on ground truth experience from selected sites. Recognized boundaries of seagrass beds varied with contrast between seagrass and sediment color, presence of algae and visibility of the day. Decisions were supported by ground truth knowledge from almost all sites visited at least once over the last three decades, and from aerial surveys in previous months of the same year. After landing, a synthesis was prepared on the basis of three individual maps obtained from each flight and transferred into a vector based geographical information system. Geometries are stored as coordinates in the Gauss-
Krueger system of the third longitudinal zone. In the area under investigation this system has a high accuracy (spatial error $<1 \%$ ) allowing the direct use for spatial statistics. Data from August/September 1994-2006 were superimposed to identify persistent beds and to estimate the total area where seagrass had been growing in that period.

\section{Results}

A recurrent pattern of seagrass beds getting denser and larger from June to August is apparent (Fig. 1). From August onwards, shed leaves were accumulating at high tide wash lines and the coverage in the meadows began to decline. Subsequent records refer to August/September as the approximate seasonal maximum.

To obtain an overview, observations from 13 consecutive years have been superimposed (Fig. 2). An area of $187 \mathrm{~km}^{2}$ or $\sim 20 \%$ of intertidal flats was found with seagrass including beds observed only once. More frequent occurrences of seagrass with observations in $>4$ years were found on $54.5 \mathrm{~km}^{2}$ (5.8\% of intertidal flats), and of these highly persistent beds observed in $>8$ years covered $22.5 \mathrm{~km}^{2}$ (2.4\% of intertidal flats). Only $12.0 \%$ of the total seagrass area consisted of permanent or almost permanent beds.

At first sight, the spatial pattern may seem haphazard. However, more intertidal area is covered within $3 \mathrm{~km}$ distance of island shores (excluding exposed beaches on the western shores of barrier islands) than of the mainland shore, with 43 versus $25 \mathrm{ha} \mathrm{km}^{-1}$ of shoreline respectively. Tidal flats without seagrass are often areas of the lower shore further off the islands or the upper shore along the mainland. Furthermore, tidal flats exposed to a long fetch

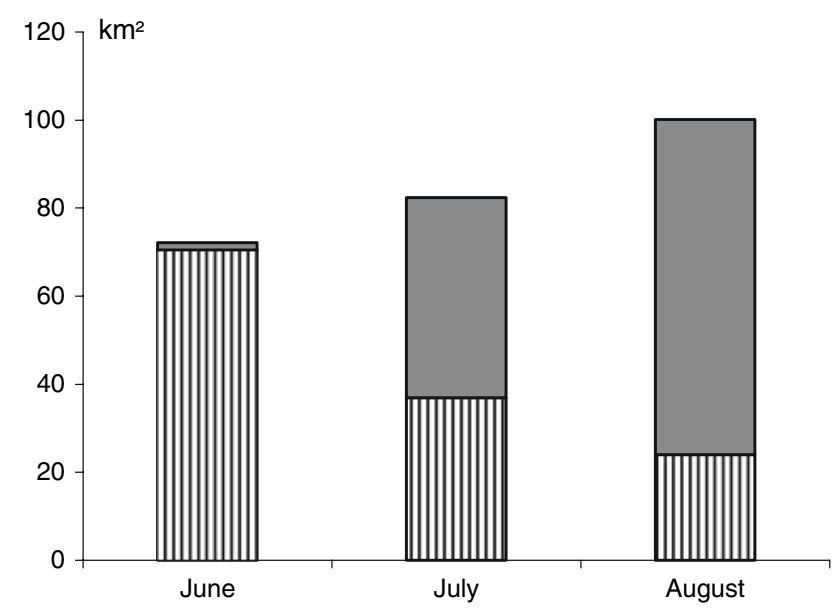

Fig. 1 Seagrass beds with low (20-50\%, hatched) and high (>50\% coverage, shaded) from June to August 2006 in the Northfrisian Wadden Sea 


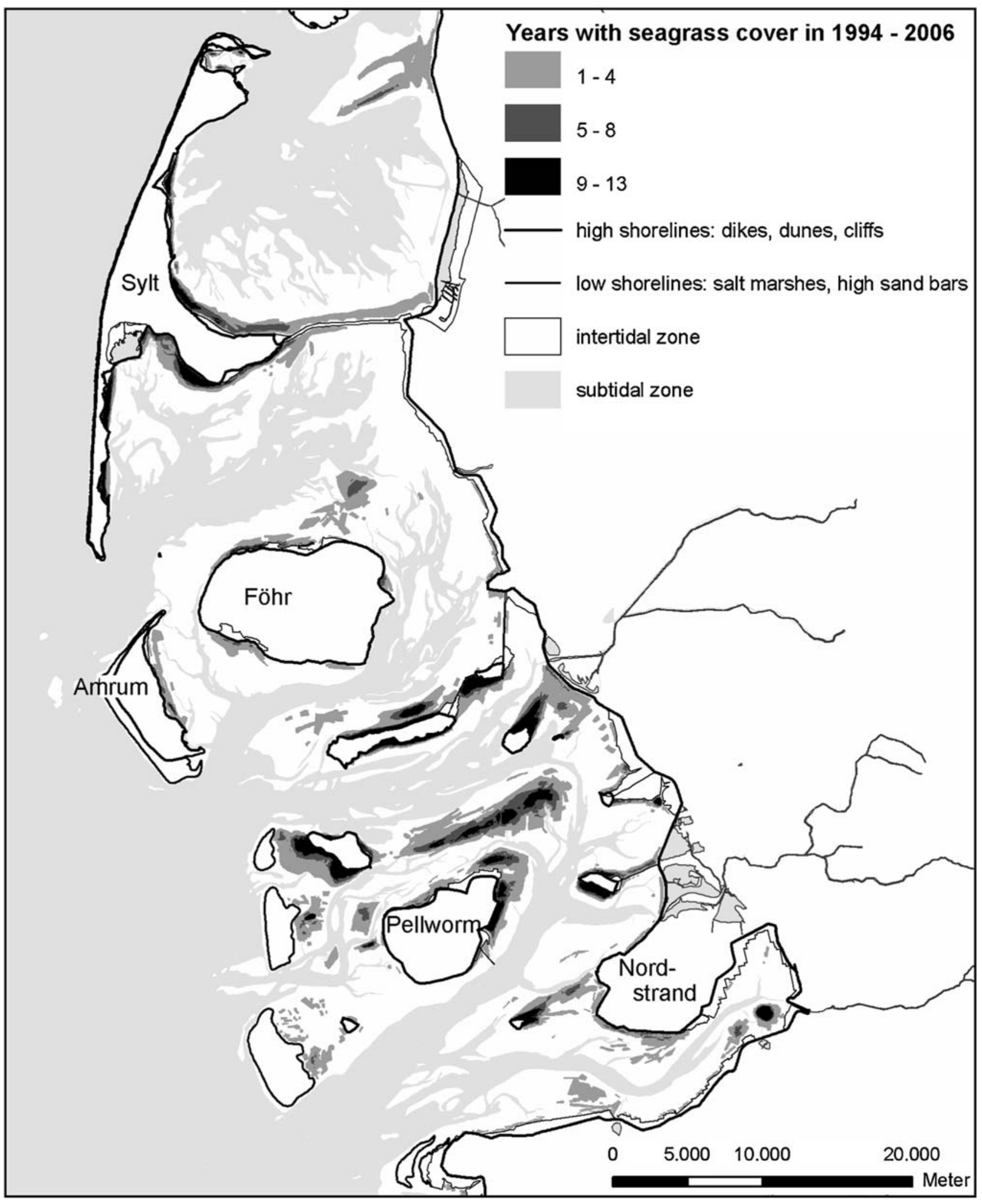

Fig. 2 Occurrence of seagrass (Zostera noltii and Z. marina) in the intertidal zone of the Northfrisian Wadden Sea in August/September 19942006. Intensity of shading refers to the number of years seagrass has been observed. Beds with < $20 \%$ coverage are not included (see "Methods") 
from southwest to west are often with no or few seagrass beds.

The timeline of area covered by seagrass shows a significant positive trend from 1994 to $2006(y=15.9+5.2 x$, $\left.r^{2}=0.8, P<0.05\right)$, with a notable increase over the last 6 years (Fig. 3). Mean area covered over this period was $52 \pm 22 \mathrm{~km}^{2}$, the smallest area covered was in 1994 with $31.7 \mathrm{~km}^{2}$, and the largest was in the last year with $100.2 \mathrm{~km}^{2}$. In addition to the 13 consecutive years, area estimates obtained with the same method for 1978 and 1991 are included in Fig. 3, both falling within the range of 1994-2006. The survey in 1991 was met with difficulties because at that time green algal mats attained peak coverage, were mixed with seagrass and confounded the estimate. Furthermore, a ground truth survey in 1992 covering about half of the region (Bock and Brodowski 1993) revealed large areas with scattered growth of $Z$. marina, indicating an expansion phase of this species. This was not observed in 1978 and was rare in the later period. Z. noltii has been by far the dominating species in terms of area occupied in the period 1994 to 2006 (pers. communication by A. Schanz, M. Loebl and own obs.).

\section{Discussion}

The Wadden Sea of the Dutch, German and Danish North Sea coast comprises the largest coherent zone of tidal flats in the world, famous for its huge flocks of migratory birds feeding there at low tide. Only in the northern part of the Wadden Sea, the seagrass habitat still takes a large share of the intertidal (Reise et al. 2005). Any significant change in seagrass cover will have effects on the entire ecosystem and may be used as an indicator for the ecological quality of the coastal waters. Therefore it is important to discuss the reliability of the long-term observations presented here, to interpret the spatial and temporal patterns and-if possible- to anticipate future developments of seagrass area.

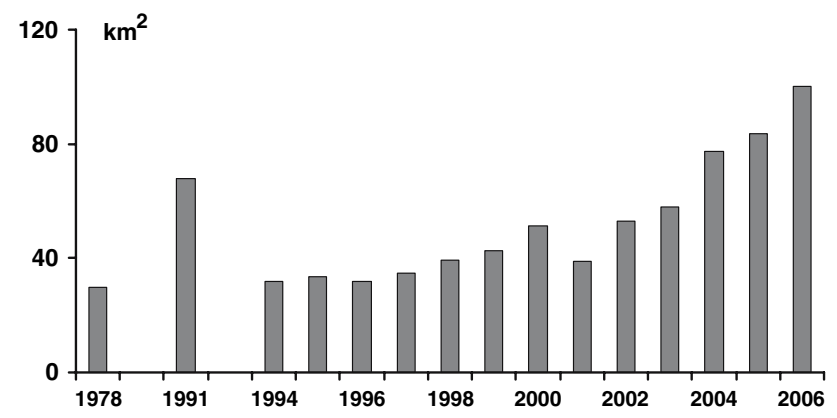

Fig. 3 Area $\left(\mathrm{km}^{2}\right)$ of seagrass beds ( $>20 \%$ coverage) recorded by aerial surveys in the Northfrisian Wadden Sea in August 1978, 1991 and 1994 to 2006
How reliable are aerial surveys?

Mapping seagrass by flying across tidal flats during low tide exposure is a rough but the only feasible rapid-assessment method when areal size is as large as the Northfrisian Wadden Sea with seagrass beds scattered throughout. Observers need experience before reproducible results can be achieved, and the first author participated in all flights to secure continuity in the method. In spite of that, there are three main causes of error when mapping seagrass from the air:

\section{Error of identification}

Seagrass beds appeared to be darker than ambient unvegetated flats but the possible confusion with green algal mats and a lack of contrast with dark and muddy sediments confounded seagrass mapping. In addition to dark shading, texture provided a cue. Intertidal seagrass beds often but not always generate a hummock structure with small runnels in between while green algal mats appear to be more homogeneous. At a low coverage, green algae were composed of elongated patches oriented in current direction, while patches of seagrass are either circular or irregular in shape. Color is highly variable because of sunlight effects, water cover and epiphytes on seagrass, and is therefore of little help in identification. Where green algae covered seagrass entirely, areas were not mapped as seagrass beds, although the seagrass underneath may have been still alive. Of course, it was not possible to separate the two species of Zostera from the air.

\section{Error of area}

Based on ground truth experience we estimate that the visible boundary of a seagrass bed looked at from 300 to $500 \mathrm{~m}$ altitude corresponded roughly to $20 \%$ coverage by seagrass at low tide exposure. However, this varies with the contrast between seagrass and sediment color and with the presence of algae. The latter were often more abundant at seagrass bed margins than in central parts. This is likely to give rise to incorrect decisions on bed boundaries.

\section{Error of location}

Seagrass beds occurring close to shore could be better located than seagrass beds further away from shores due to the availability of topographic cues. Varying water levels caused the low tide line and the course of gullies to be less useful for orientation. However, in the Northfrisian Wadden Sea most seagrass beds occur close to shore. Twenty islands and high sandy shoals and also mussel beds helped in positioning seagrass beds correctly. 
The errors mentioned above sum up to underestimate persistence of individual seagrass beds. Since coverage less than about $20 \%$ is not detectable from the air, persistence at a lower density has been missed. Therefore, the estimated $12 \%$ of seagrass area occupied over at least two thirds of the period of investigation is a minimum figure. Nevertheless, the large area where seagrass was observed only over up to one third of the period indicates a highly dynamic state of seagrass populations in the area. Within intervals of $\sim 7$ years, Frederiksen et al. (2004a, b) also observed considerable areal changes (39-62\%) of Z. marina in shallow Danish waters based on aerial photographs. An analysis of a set of aerial photographs of the North Frisian Wadden Sea available for August 2005 came up with an area estimate similar to the flight observations $(+12 \%$; Poszig et al., in prep.). However, the interpretation of aerial photographs was not independent from the other aerial surveys and from ground truth knowledge. Aerial photographs can eliminate the error of incorrect positioning but otherwise are subject to the same problems of identifying and delimiting seagrass area, and take more time and costs. Satellite images cannot account for the tidal time lag within the area, and require a cloud-free sky at low tide which is rarely met. In conclusion, we recommend to continue with the rapid-assessment of seagrass area by means of direct flight observations.

What causes the spatial pattern?

We hypothesize that a key factor in the occurrence of seagrass beds in the study area is sediment stability. The spatial pattern of seagrass beds in the northern Wadden Sea as shown in Fig. 2 may be explained by (1) sediment mobility too high for seagrass to occur on sandy flats exposed to a long fetch from the prevailing southwesterly and westerly winds, (2) islands and high sands providing shelter against wave disturbances originating from that direction, (3) clay from former salt marshes underlying soft tidal sediments and facilitating sediment stability and firm rooting, and (4) sediment accretion rates being too high for seagrass in the nearshore zone along the mainland coast. To confirm this, a field survey on sediment dynamics needs to be conducted. An emphasis on sediment stability shall not reject other factors often discussed for seagrass distribution such as sediment type, tidal level, hydrodynamics, light availability, salinity, nutrient over-supply and herbivory. However, for the spatial pattern in the northern Wadden Sea these other factors or any combination of them do not seem to provide a consistent cue to the observed pattern.

Cabaço and Santos (2007) conducted short-term burial and erosion experiments with $Z$. noltii which is lacking a vertical rhizome. They found negative effects on shoot density even when the sediment level was altered by a few centimeter only. A similar sensitivity was found for Z. marina by Mills and Fonseca (2003). Incidences of wave erosion have been observed to expose roots and rhizomes. Such patterns occur on a small scale $(10$ to $100 \mathrm{~m})$ at moving ridges of sand (Cunha et al. 2005, own obs.), and may also apply to the scale of entire tidal flats $(\mathrm{km})$ with an unbalanced sediment budget or with a high internal sediment mobility. A rather stable sediment surface layer seems to be a pivotal condition.

Sandy flats of the lower tidal zone exposed to waves with a long fetch from the prevailing wind directions may be too dynamic for seagrass to become established. In a model calculation, Philippart et al. (1992) found Z. marina and $Z$. noltii to be equally sensitive to sediment instability. Patch dynamics of $Z$. marina have been attributed to sediment movement (Harlin and Thorne-Miller 1982). Attempts to restore Z. marina beds in the southern Wadden Sea failed in exposed areas lacking sufficient shelter (Bos and van Katwijk 2007; van Katwijk 2003). Van Katwijk and Hermus (2000) stabilized sediments artificially with shell fragments. This facilitated survival of transplanted $Z$. marina at exposed but not at sheltered locations. Usually the source of sediment instability is wave exposure or high current velocity which in addition are known to have direct adverse effects on seagrass (Fonseca and Bell 1998; Schanz and Asmus 2003; van Katwijk and Wijgergangs 2004).

Although in the northern Wadden Sea most seagrass beds occur in the leeward shelter of islands and high sands, not all fit into that pattern (Fig. 2). Deviations can be explained by layers of dense clay underneath the sediment surface. These are remnants of former salt marshes. All of the marshy islands were once larger and hence are surrounded by remnant clay layers at variable depth below the sediment surface (e.g. Bantelmann 1966; Plath 1943). This also applies to the largest seagrass bed found in the study area which occurs north of the island of Pellworm ("Pellwormer Plate"). Clay layers and occasionally also layers of compressed peat may not only keep away lugworms but also provide a firm rooting (Fig. 4).

Philippart (1994) conducted transplant experiments at such a site. Z. noltii that grew above a layer of clay was not capable to grow outside a clay area. In the presence of the bioturbating lugworm Arenicola marina it did not persist. Conversely, lugworms did not settle above the clay because of an insufficient depth of soft sediment for burrowing. Exclusion of lugworms also may facilitate seagrass colonization. On lugworm exclusion plots (Volkenborn et al. 2007), patches of $Z$. noltii began to show up after 5 years in significantly higher numbers than on control plots where bioturbating lugworms remained present (N. Volkenborn, pers. comm.).

Dense patches of Z. noltii and Z. marina tend to trap particles and generate hummocks (Bos et al. 2007). A surplus supply of deposits may soon exceed what can be tolerated. 


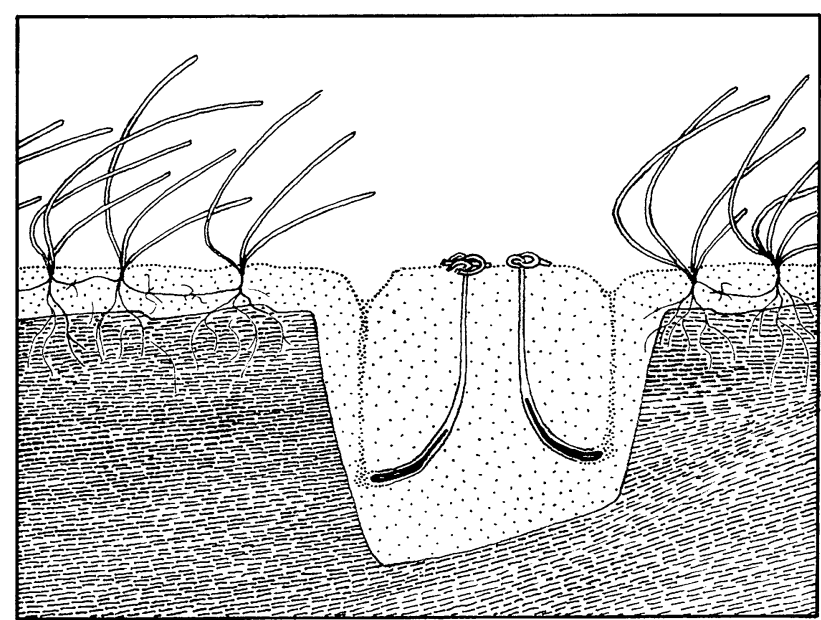

Fig. 4 Firm clay of drunken medieval marshland superimposed by marine sediments. Former drainage ditch provides sufficient sediment depth for Arenicola marina. By bioturbation the lugworm inhibits the seagrass Zostera noltii. Schematic from observations at Hallig Hooge, Nordstrandischmoor and Pellworm (see text)

Along the mainland shore, most salt marshes were found to extend seaward between 1988 and 2001 (Stock et al. 2005). This indicates a rising of nearshore flats, almost always enforced by rectangular grids of brushwood groins. These are permeable fences made of brushwood wedged between parallel rows of wooden poles. They are employed to enhance deposition. The ultimate aim is to gain saltmarsh area in front of dikes in order to dissipate storm surge wave energy. Sedimentation rates of 100 to $400 \mathrm{~mm}$ have been achieved within 3 years (Erchinger et al. 1996). Such land claim activities along the mainland shore exceed the ability of $Z$. noltii to cope with burial. This may explain the relative scarcity of seagrass in front of the mainland as shown in Fig. 2.

Land reclamation fields with brushwood groins are subjected to recurrent excavation of drainage ditches. This is lethal to seagrass. Groins also tend to trap green drift algae. These accumulate and then suffocate the seagrass underneath (Reise and Siebert 1994; Bos and van Katwijk 2007).

Why a positive trend?

On a world-wide scale seagrass beds are declining due to increased human pressure in the form of (1) nutrient loading mainly at developed coasts in the temperate zone, (2) siltation linked to coastal deforestation mainly in the tropics, and (3) various mechanical disturbances such as dredging (Hemminga and Duarte 2000; den Hartog and Phillips 2001; Green and Short 2003; Burkholder et al. 2007). The positive seagrass development observed in the northern Wadden Sea is opposite to the global trend. Also in the southern Wadden Sea a former decline (de Jonge et al. 1993; Kastler and Michaelis 1999) seems to have come to a halt (Reise et al. 2005). We here argue that the main cause for the increasing trend in seagrass area in the northern Wadden Sea has been a decrease in storminess since 1995 which entails a decrease in sediment mobility.

Although still far above pre-industrial level, riverine nutrient loadings have been decreasing over the last two decades (van Beusekom et al. 2005, this volume). Experiments have shown direct and indirect negative effects of reactive nitrogen on $Z$. noltii and $Z$. marina (Philippart 1995; van Katwijk et al. 1997, 1999; Burkholder et al. 2007). The level of eutrophication is higher in the southern than in the northern Wadden Sea (van Beusekom 2006). Thus, one would not expect a synchronous response of seagrass throughout the entire region as it seems to be the case. Massive green algal mats are believed to have been triggered by eutrophication (Fletcher 1996). They peaked in the intertidal German Wadden Sea in the early 1990s, since then declined, fluctuated from year to year but did not cease altogether (Reise and Siebert 1994; Kolbe et al. 1995; van Beusekom et al. 2005). Green algal mats are capable of extinguishing beds of seagrass by suffocation (den Hartog 1994; Cardoso et al. 2004) but at the scale of the entire Northfrisian Wadden Sea no inverse relation of green algal area and seagrass area is apparent (own unpubl. data).

Schanz et al. (2002) suggested a synergistic effect of eutrophication and hydrodynamics. Experiments showed that massive fouling by microalgae on seagrass leaves could only be prevented by grazers such as the snail Hydrobia ulvae under calm conditions. With increasing current velocity grazers failed to control fouling and fouling may have been facilitated by an ample supply of nutrients. Hydrodynamics also directly affect density and shoot morphology of Z. noltii (Schanz and Asmus 2003). These experimental studies support the idea that changes in wave pattern and storm surge frequency could be responsible for the observed areal increase in seagrass beds over the last decade. Decreasing mechanical disturbances such as bivalve dredging or bottom trawling (Marencic 2005) may not have caused the seagrass expansion. Such disturbances are local and their recession cannot account for a recovery of seagrass throughout the Wadden Sea.

A regionally consistent trend in seagrass areal development may be better explained by a decrease in storm surge levels since the mid 1990s which has been indicated by Weisse and Plüß (2006). Considering winter periods (November-March) in the German Bight, an increase in storm activity since the 1960s with highest levels around 1990-1995 was followed by a decrease. Storm surge water levels in summer (April-October) showed a slight decrease over the entire period. It needs to be experimentally investigated whether storm related sediment instability in winter is relevant for subsequent seagrass development. If true, we have to predict that an anomalous storm frequency 
observed November-December 2006 will have a negative effect on seagrass bed area in 2007. This supposition would be in line with the pivotal role of sediment stability in explaining the spatial pattern of seagrass beds.

\section{May seagrass continue to expand?}

Not knowing for sure what has caused the recent positive trend in seagrass area, it is obviously impossible to make a prediction. Further, it is not clear whether the expansion of seagrass area over a couple of years is part of a decadal fluctuation or the beginning of a recovery. The latter rests on the assumption that the occurrence of Zostera spp. all over the tidal zone and in patches into the upper subtidal as observed eighty years ago by Nienburg (1927) and Harmsen (1936) resembles a pristine condition which could return once human pressures have relaxed.

Intermittent area extensions of annual Z. marina beds in the intertidal zone has been repeatedly observed (Reise et al. 1989, 2005; Bock and Brodowski 1993). However, the positive trend over the last decade is a gradual expansion by perennial $Z$. noltii and thus may constitute a longterm recovery.

If lack of sediment stability is indeed the most important limiting factor, then seagrass beds could still expand beyond the maximum cover observed in 2006. At least the entire area shaded in Fig. 2 might be regarded as potential seagrass area which is almost twice the extent of 2006. Of course, this may never be realized and only holds if climatic forcing does not entail a decrease in sediment stability by increasing water levels at the Northfrisian coast. Extrapolating winter storm surge levels observed at tide gauges over the last four decades (Weisse and Plüß 2006) into the next 40 years, would raise water levels by about half a meter, irrespective of any acceleration in global sea level rise. In the long run such a development would be disadvantageous for intertidal seagrass beds because a fixed dikeline precludes areal adjustments. Increased land claim activities by means of brushwood groins to enhance saltmarsh progression would be at the expense of potential seagrass area.

Acknowledgments We thank the pilots, R. Doerffer, K. Hansen, and in particular J. Meyer-Brenkhof, who always brought us softly back to the ground. Thanks go to the many volunteers who helped mapping seagrass from the air (A. Albrecht, L. Baumann, J. van Beusekom, F. Buhs, C. Buschbaum, A. Chapman, S. Diederich, T. Dolch, G. Donner, K. Gärtner, S. Görlitz, C. Grafe, A. Halbe, C. Hass, N. Hernandez, W. Hickel, S. Junge, C. Junghans, P. Kadel, D. Kirchner, I. Kruse, D. Lackschewitz, C-G Lee, C. Leuschner, M. Loebl, H. Lotze, I. Menn, M. Nacken, N. Okun, U. Pieroth, P. Polte, K. Prinz, M. Quack, T. Reinwald, D. Reise, B. Saier, A. Schanz, P. Schieck, D. Schories, A. Schürmann, M. Simon, M. Strasser, D. Thieltges, N. Volkenborn, D. Wethey, M. Wetzel, B. Wilmes, S. Wolf, A. Zipperle. Anja Schanz, Martina Loebl and Tobias Dolch contributed important insights from their ground surveys, and Dörte Poszig and Georg Nehls from analyzing aerial photographs. Comments by Marieke van Katwijk greatly improved the manuscript. Funding was provided by the Landesamt für den Nationalpark Schleswig-Holsteinisches Wattenmeer within the framework of TMAP. The authors acknowledge the support by the MARBEF Network of Excellence "Marine Biodiversity and Ecosystem Functioning" which is funded in the Community's Sixth Framework Programme (contract no. GOCE-CT-2003-505446).

\section{References}

Asmus H, Asmus R (2000) Material exchange and food web of seagrass beds in the Sylt-Rømø Bight: how significant are community changes at the ecosystem level? Helgol Mar Res 54:137-150

Bantelmann A (1966) Die Landschaftsentwicklung an der schleswigholsteinischen Westküste, dargestellt am Beispiel Nordfriesland. Die Küste 14(2):5-99

Bock H, Brodowski A (1993) Seegras- und Grünalgenbestände im Nordfriesischen Wattenmeer unter besonderer Berücksichtigung ökologischer Faktoren. Diplomarbeit FB Geowissenschaften, Univ Münster, Germany

Borum J, Duarte CM, Krause-Jensen D, Greve TM (2004) European seagrasses: an introduction to monitoring and management. EU project monitoring and managing of European seagrasses. http:// www.seagrasses.org

Bos AR, van Katwijk MM (2007) Planting density, hydrodynamic exposure and mussel beds affect survival of transplanted intertidal eelgrass. Mar Ecol Prog Ser 336:121-129

Bos AR, Bouma TJ, de Kort GJL, van Katwijk MM (2007) Ecosytsem engineering by annual intertidal seagrass beds: sediment accretion and modification. Estuar Coast Shelf Sci 74:344-348

Burkholder JM, Tomasko DA, Touchette BW (2007) Seagrasses and eutrophication. J Exp Mar Biol Ecol 350:46-72

Cabaço S, Santos R (2007) Effects of burial and erosion on the seagrass Zostera noltii. J Exp Mar Biol Ecol 340:204-212

Cardoso PG, Pardal MA, Lillebø AI, Ferreira SM, Raffaelli D, Marques JC (2004) Dynamic changes in seagrass assemblages under eutrophication and implications for recovery. J Exp Mar Biol Ecol 302:233-248

Cunha A, Santos R, Gaspar P, Bairros M (2005) Seagrass landscapescale changes in response to disturbance created by the dynamics of barrier-islands: a case study from Ria Formosa (South Portugal). Estuar Coast Shelf Sci 64:636-644

de Jonge VN, Essink K, Boddeke R (1993) The Dutch Wadden Sea: a changed ecosystem. Hydrobiologia 265:45-71

den Hartog C (1970) The sea-grasses of the world. North-Holland Publ Comp, Amsterdam

den Hartog C (1971) The dynamic aspect in the ecology of seagrass communities. Thalassia Jugosl 7:101-112

den Hartog C (1994) Suffocation of a littoral Zostera bed by Enteromorpha radiata. Aquat Bot 47:21-28

den Hartog C, Phillips RC (2001) Common structures and properties of seagrass beds fringing the coasts of the world. In: Reise K (ed) Ecological Comparisons of Sedimentary Shores. Ecological studies, vol 151. Springer, Heidelberg, pp 195-212

Erchinger HF, Coldewey H-G, Meier C (1996) Interdisziplinäre Erforschung des Deichvorlandes im Forschungsvorhaben "Erosionsfestigkeit von Hellern". Die Küste 58:1-45

Fletcher RL (1996) The occurrence of green tides-a review. In: Schramm W, Nienhus PH (eds) Marine benthic vegetation. Ecological Studies. Springer, Heidelberg, pp123:7-43

Fonseca MS, Bell SS (1998) Influence of physical setting on seagrass landscapes near Beaufort, North Carolina, USA. Mar Ecol Prog Ser 171:109-121 
Frederiksen M, Krause-Jensen D, Holmer M, Laursen JS (2004a) Spatial and temporal variation in eelgrass (Zostera marina) landscapes: influence of physical setting. Aquat Bot 78:147-165

Frederiksen M, Krause-Jensen D, Holmer M, Laursen JS (2004b) Long-term changes in area distribution of eelgrass (Zostera marina) in Danish coastal waters. Aquat Bot 78:167-181

Green EP, Short TF (2003) World Atlas of Seagrasses. University of California Press, Berkeley

Harlin MM, Thorne-Miller B (1982) Seagrass-sediment dynamics of a flood tidal delta in Rhode Island (USA). Aquat Bot 14:127-138

Harmsen GW (1936) Systematische Beobachtungen der NordwestEuropäischen Seegrasformen. Nederlands Kruidkundig Archief 46:852-877

Hemminga MA, Duarte CM (2000) Seagrass ecology. Cambridge University Press, Cambridge

Kastler T, Michaelis H (1999) The decline of seagrasses, Zostera marina and Zostera noltii, in the Wadden Sea of Lower Saxony. Senckenbergiana maritima 29:77-80

Kolbe K, Kaminski E, Michaelis H, Obert B, Rahmel J (1995) Macroalgal mass development in the Wadden Sea: first experiences with a monitoring system. Helgol Meeresunters 49:519-528

Marencic H (2005) Fishery. In: Essink K, et al (eds) Wadden sea quality status report 2004. Wadden Sea ecosystem 19. Common Wadden Sea Secretariat, Wilhelmshaven, pp 49-56

Mills KE, Fonseca MS (2003) Mortality and productivity of eelgrass Zostera marina under conditions of experimental burial with two sediment types. Mar Ecol Prog Ser 255:127-134

Nacken M, Reise K (2000) Effects of herbivorous birds on intertidal seagrass beds in the northern Wadden Sea. Helgol Mar Res 54:87-94

Nienburg W (1927) Zur Ökologie der Flora des Wattenmeeres. I. Der Königshafen bei List auf Sylt. Wiss Meeresunters (Abt Kiel) 20:146-196

Philippart CJM (1994) Interactions between Arenicola marina and Zostera noltii on a tidal flat in the Wadden Sea. Mar Ecol Prog Ser 111:251-257

Philippart CJM (1995) Effect of periphyton grazing by Hydrobia ulvae on the growth of Zostera noltii on a tidal flat in the Dutch Wadden Sea. Mar Biol 122:431-437

Philippart CJM, Dijkema KS, Meer van der J (1992) Wadden Sea seagrasses: where and why? Neth Inst Sea Res Publ Ser 20:177-191

Plath M (1943) Die biologische Bestandsaufnahme als Verfahren zur Kennzeichnung der Wattsedimente und die Kartierung der nordfriesischen Watten. Westküste 2:7-46

Polte P, Schanz A, Asmus H (2005) The contribution of seagrass (Zostera noltii) cover to the function of tidal flats as a juvenile habitat for dominant, mobile epibenthos in the Wadden Sea. Mar Biol $147: 813-822$

Reise K, Siebert I (1994) Mass occurrence of green algae in the German Wadden Sea. Dt Hydrogr Z (Suppl) 1:171-180

Reise K, Herre E, Sturm M (1989) Historical changes in the benthos of the Wadden Sea around the island of Sylt in the North Sea. Helgol Meeresunters 43:417-433
Reise K, Jager Z, de Jong D, van Katwijk M, Schanz A (2005) Seagrass. In: Essink K, et al (eds) Wadden sea quality status report 2004. Wadden Sea ecosystem 19. Common Wadden Sea Secretariat, Wilhelmshaven, pp 201-207

Schanz A, Asmus H (2003) Impact of hydrodynamics on development and morphology of intertidal seagrasses in the Wadden Sea. Mar Ecol Prog Ser 261:123-134

Schanz A, Polte P, Asmus H (2002) Cascading effects of hydrodynamics on an epiphyte-grazer system in intertidal seagrass beds of the Wadden Sea. Mar Biol 141:287-297

Short F, Carruthers T, Dennison W, Waycott M (2007) Global seagrass distribution and diversity: a bioregional model. J Exp Mar Biol Ecol 350:3-20

Stock M, Gettner S, Hagge M, Heinzel K, Kohlus J, Stumpe H (2005) Salzwiesen an der Westküste von Schleswig-Holstein 19882001. Schriftenreihe des Nationalparks Schleswig-Holsteinisches Wattenmeer 15:1-239

van Beusekom JEE (2006) Eutrophication proxies in the Wadden Sea: regional differences and background concentrations. DMU Technical Reports 573:45-51

van Beusekom J, Bot P, Göbel J, Hanslik M, Lenhart HJ, Pätsch J, Peperzak L, Petenati T, Reise K (2005) Eutrophication. In: Essink $\mathrm{K}$, et al (eds) Wadden sea quality status report 2004. Wadden Sea ecosystem 19. Common Wadden Sea Secretariat, Wilhelmshaven, pp 141-154

van Katwijk MM (2003) Reintroduction of eelgrass (Zostera marina L.) in the Dutch Wadden Sea: a research overview and management vision. In: Wolff WJ, Essink K, Kellermann A, van Leeuwe MA (eds) Challenges to the Wadden Sea. Univ. of Groningen, Groningen, pp 173-195

van Katwijk MM, Hermus DCR (2000) Effects of water dynamics on Zostera marina: transplantation experiments in the intertidal Dutch Wadden Sea. Mar Ecol Prog Ser 208:107-118

van Katwijk MM, Wijgergangs LJM (2004) Effects of locally varying exposure, sediment type and low-tide cover on Zostera marina recruitment from seed. Aquat Bot 80:1-12

van Katwijk MM, Vergeer LHT, Schmitz GHW, Roelofs JGM (1997) Ammonium toxicity in eelgrass Zostera marina. Mar Biol Prog Ser 157:159-173

van Katwijk MM, Schmitz GHW, Gasseling AM, van Avesaath PH (1999) The effects of salinity and nutrient load and their interaction on Zostera marina L. Mar Ecol Prog Ser 190:155-165

Volkenborn N, Hedtkamp SIC, van Beusekom JEE, Reise K (2007) Effects of bioturbation and bioirrigation by lugworms (Arenicola marina) on physical and chemical sediment properties and implications for intertidal habitat succession. Estuar Coast Shelf Sci 74:331-343

Weisse R, Plüß A (2006) Storm-related sea level variations along the North Sea coast as simulated by a high-resolution model 1958 2002. Ocean Dyn 56:16-25

Wohlenberg E (1935) Beobachtungen über das Seegras Zostera mari$n a$ L. und seine Erkrankung im nordfriesischen Wattenmeer. Nordelbingen 11:1-19 